\title{
External auditors' reliance on internal audit: the impact of sourcing arrangements and consulting activities
}

\author{
By \\ Lois Munro \\ Queensland University of Technology \\ Australia \\ and \\ Jenny Stewart \\ Griffith University \\ Australia
}

Key Words: internal audit; external auditor reliance decisions; internal audit outsourcing; internal audit consultancy activities

JEL Classification: M42

\section{Acknowledgements:}

We acknowledge the helpful comments of Sherrena Buckby, Jan Hollindale, Pamela Kent, Gary Monroe, Nava Subramaniam, Ken Trotman, and participants at the Australian National Centre for Audit and Assurance Research Forum, Canberra, November 2007, the British Accounting Association Auditing Special Interest Group, 18th National Auditing Conference, Cardiff, April 2008 and the European Accounting Association $31^{\text {st }}$ Annual Congress, Rotterdam, April 2008. The financial support of Queensland University of Technology and Griffith University is also gratefully acknowledged.

\section{Contact Author:}

Professor Jenny Stewart

Department of Accounting, Finance \& Economics, Griffith Business School,

Griffith University,

University Drive, Meadowbrook, Queensland, 4131

Australia

Ph: 61733821192

Fax: 61733821128

Email: j.stewart@griffith.edu.au

July 2009 


\title{
External auditors' reliance on internal audit: the impact of sourcing arrangements and consulting activities
}

\begin{abstract}
This study examines the impact of internal audit outsourcing and internal audit's involvement in consulting on external auditors' reliance on the work of internal audit. We test whether these factors influence (i) reliance on internal audit work already undertaken and (ii) the use of internal auditors as assistants. In each case, we distinguish between control evaluation and substantive testing. We find that involvement in consulting impacts reliance on work undertaken and the use of internal auditors as assistants for control evaluation. External auditors make greater use of internal auditors as assistants for substantive testing when internal audit is provided in-house. Overall, external auditors use internal audit more for control evaluation tasks than for substantive testing.
\end{abstract}

Key Words: internal audit; external auditor reliance decisions; internal audit outsourcing; internal audit consultancy activities

JEL Classification: M42 


\section{Introduction}

Reliance on the work of internal audit affects the nature, timing and extent of audit procedures performed by the external auditor (International Auditing Standard ISA 610). Hence, the extent to which the external auditor relies on internal audit work is a key audit planning decision which can have a significant impact on audit fees (Felix et al., 2005 and 2001). In recent years, however, internal audit activities have been extended so that the function no longer has a narrow focus based on evaluating and strengthening internal controls (Gramling et al., 2004, Cohen et al., 2004). This is reflected in the Institute of Internal Auditors (IIA) definition of internal auditing which stresses that internal audit is both an assurance activity and a consulting activity (IIA, 1999), playing a key role in corporate governance and risk management. At the same time, the practice of outsourcing internal audit has become increasingly prevalent (Glover et al., 2008; Ernst \& Young, 2006), with internal audit services being offered by specialist providers as well as by more traditional accounting firms. These changes in the role of internal audit are likely to impact external auditors' reliance decisions.

While there have been three decades of research exploring external auditors' reliance on the work of internal audit (for example, Clark et al., 1980; Schneider, 1985; Margheim, 1986; Whittington and Margheim, 1993; Gramling et al., 2004), much of this research was conducted when internal audit had a narrower focus and was only offered in-house. Both the provision of consulting services by the internal audit function and the sourcing arrangement of internal audit have the potential to impact internal audit objectivity. Hence, they could influence external auditors' decisions to rely on the work of internal audit. In this study, we use an experimental 
design to examine the impact of these two factors on external auditors' reliance decisions.

We extend prior research in a number of key ways. First, our consulting manipulation examines the impact of an internal audit function that has been actively engaged in systems consulting in relation to the financial system, an issue not addressed in prior research. Second, in contrast to prior studies, our sourcing arrangement manipulation involves the use of a specialist internal audit firm rather than an accounting firm as the external provider (Glover et al., 2008; Gramling and Vandervelde, 2006). Even though outsourcing to specialist firms is becoming more common, external auditors' perceptions of this practice have not previously been investigated. In addition, this manipulation allows us to remove the possibility of group affiliation bias which can arise when auditors rely on work outsourced to another auditing firm (Gramling and Vandervelde, 2006). Third, by investigating the sourcing arrangement and the provision of consulting services together in a $2 \times 2$ experiment, we are able to examine whether they have a joint effect on the dependent variables (DeZoort et al., 2001).

A fourth contribution is that we provide a more in-depth analysis of external auditors' reliance decisions by examining the impact of internal audit on four separate decisions. These include the decision to rely on work already undertaken by internal audit and the decision to utilise internal auditors to perform certain audit tasks. For both of these decisions, we further differentiate between control evaluation work and substantive testing of balances. No prior studies have used these four reliance decisions as dependent variables in the one study. However, previous research has found that the impact of factors affecting external auditors' reliance on internal audit can differ between control evaluation and substantive testing (Margheim, 1986; Mills, 
1996) and between reliance on work undertaken by internal audit and using internal auditors as assistants (Margheim and Label; 1990).

We manipulate (i) internal audit involvement in systems consulting at either a high involvement role or no involvement and (ii) sourcing arrangement as the internal audit function either being provided in-house or by a specialist internal audit and business risk consulting firm. We examine the effect of these factors on the four reliance decisions noted above. We find that internal audit involvement in systems consulting impacts the extent of external auditor reliance on the work of internal audit for control evaluation but not for substantive testing of balances. However, whether the function is outsourced or provided in-house does not have a significant impact on reliance decisions. An exception is that external auditors are more likely to use inhouse internal auditors to assist with substantive testing.

In addition, our overall results suggest that there are no significant differences between external auditors' use of work already undertaken by internal auditors and their use of internal auditors as assistants. However, it appears that external auditors are more likely to use internal audit for control evaluation work than for substantive testing of account balances.

The remainder of the paper is structured as follows. The next section discusses prior research and develops the hypotheses. The third section explains the research methods while the results of the study are reported and discussed in the fourth section. In the final section, some conclusions are drawn, the limitations of the study are acknowledged and suggestions for future research are provided. 


\section{Background and hypothesis development}

The current governance environment has led to an increased emphasis on the relationship between internal and external auditors (Gramling et al., 2004). The economic benefits of external auditors' reliance on internal audit work are well recognised (Glover et al., 2008). For example, Felix et al. (2001) found that audit fees were approximately 18\% lower when external auditors coordinated their work with internal audit.

ISA 610 requires external auditors to evaluate four factors when considering whether internal audit work is adequate for the purpose of their audit. These factors are objectivity, technical competence, due professional care and communication (ISA 610, 2009). In a similar vein, current US standards require external auditors to consider the competence, objectivity and work performed by internal auditors when making reliance decisions (AICPA, 2008 (AU Section 322); PCAOB, 2007). The international standard does not deal with instances when internal auditors assist the external auditor to undertake specific audit tasks. However, the US standard currently recognises that the external auditor may use internal auditors as assistants to obtain an understanding of controls, to test controls and to perform substantive tests. When direct assistance is provided, the standard requires the auditor to assess internal audit competency and objectivity.

External auditors' reliance decisions have been the focus of a large body of research, with much of the early work examining the extent to which auditors consider the key factors of objectivity, competence and work performed (see Gramling et al., 2004 for a detailed review of this research). Other factors have been explored, including the level of coordination between internal and external audit (Felix et al., 2001), internal audit remuneration incentives (DeZoort et al., 2001), 
whether internal audit has primarily an auditing focus or a consulting focus (DeZoort et al., 2001), internal audit sourcing arrangement (Glover et al., 2008), task subjectivity (Glover et al., 2008; DeZoort et al., 2001), inherent risk (Glover et al., 2008; Felix et al., 2001), non-audit services (Felix et al., 2005) and client pressure to use internal audit services (Felix et al., 2005).

In general, two main dependent variables have been used in prior studies. These are the extent of reliance on internal audit and the reduction in budgeted audit hours resulting from such reliance. A few studies have distinguished between reliance on work already performed by internal audit and using internal auditors as assistants (Abdel-Khalik et al., 1983; Margheim and Label, 1990) and between control evaluation tasks and substantive testing of balances (Margheim, 1986; Mills, 1996). Here we examine all four reliance decisions in a single study.

\subsection{Consulting role of internal audit}

The IIA definition of internal auditing highlights the role of internal audit as a provider of consulting services as well as the more traditional assurance services. The change in definition is consistent with a more value-added emphasis being placed on the internal audit function (Brody and Lowe, 2000; Cashell and Aldhizer III, 2002). Research by Nagy and Cenker (2002) indicates that the change in definition simply reflects existing practice, with internal auditors having performed consulting services and other value-added activities for many years. However, concern has been expressed about the ability of internal auditors to maintain the desired level of objectivity when acting as both consultants and assurers (Brody and Lowe, 2000). DeZoort et al. (2001) argue that a consulting role for internal audit involves participation in management decision making and the development of close working relationships with management, leading to a reluctance to report negative findings. 
Further, a self-review threat exists when internal auditors are involved in financial systems design and then at a later stage are required to audit these systems (Plumlee, 1985; Church and Schneider, 1992).

Only a small number of research studies have addressed this problem and there have been significant changes in the internal audit environment since these studies. Plumlee (1985) found that internal auditors who reviewed a system they had helped to design perceived internal controls to be stronger and were less critical of control weaknesses than those who were not reviewing their own work. In contrast, Church and Schneider (1992) failed to find support for their prediction that internal auditors would allocate fewer audit hours to investigate irregularities when they had been involved in designing internal controls. They suggest that this may indicate that internal auditors do not allow themselves to be influenced by their involvement in systems design because they are cognizant of their need to maintain objectivity.

Both Brody and Lowe (2000) and Ahlawat and Lowe (2004) examined whether internal auditors remain objective when consulting to management in a corporate acquisition setting. Both studies found that the role the company was taking in the negotiation process influenced participants' judgments, suggesting that internal auditors who act as consultants may not be able to maintain their objectivity.

DeZoort et al. (2001) tested whether internal audit participation in consulting, together with eligibility for incentive compensation, influenced external audit reliance decisions. Although they found that external auditors perceived that a consulting role would reduce internal audit objectivity and increase the likelihood of acquiescence to management, consulting had little effect on actual reliance and planning decisions. They speculate that a possible reason for their unexpected result is that, at the time of their study, external auditors actively provided consulting services to their audit 
clients, making them less sensitive to the likelihood of bias. Hence, these findings may not hold in the current environment where external auditors no longer engage in the extensive provision of non-audit services.

DeZoort et al. (2001) manipulated the overall time spent on consulting activities rather than involvement in the design of a system which the internal auditor may subsequently need to audit. The present study examines whether internal audit involvement in consultancy activities specifically relating to financial systems would influence external auditors' reliance on the work of internal audit. Further, it is undertaken at a time when the provision of non-audit services to audit clients is no longer considered appropriate. In this context, we predict that external auditors will be reluctant to rely on the work of internal auditors who have been directly involved with the design of financial systems. We also expect that they will be less likely to use these internal auditors as assistants. We therefore test the following hypotheses:

H1: External auditors are more likely to rely on work already undertaken by internal audit when internal auditors do not perform a systems consulting role compared to when they do perform such a role.

H2: External auditors are more likely to use internal audit to assist in performing audit tasks when internal auditors do not perform a systems consulting role compared to when they do perform such a role.

\subsection{Internal audit sourcing arrangement}

Outsourcing of internal audit activities has become commonplace in recent years (Ernst \& Young, 2006; Caplan and Kirschenheiter, 2000). While it is no longer acceptable for external auditors to provide internal audit services to their audit clients (Sarbanes-Oxley Act, (SOX), 2002), outsourcing services are provided both by public 
accounting firms to non-audit clients and by specialist internal audit firms (Ernst \& Young, 2006).

It has been argued that an in-house internal audit function may be less objective than an outsourced function as it is difficult for an employee to be truly independent of management (James, 2003; Glover et al., 2008; Ahlawat and Lowe, 2004). It has also been suggested that outside internal audit providers, particularly the large accounting firms, offer high quality services and may have a greater level of expertise, especially with regard to specialist knowledge such as technology skills (Caplan and Kirschenheiter, 2000). ${ }^{1}$ However, outside providers lack the in-depth company knowledge possessed by in-house internal auditors (James, 2003). This reflects the IIA (1994) argument that a competent in-house internal audit department "can perform the internal auditing function more efficiently and effectively than a contracted audit service” (IIA, 1994, p. 2).

Felix et al. (2001) report that the contribution of internal audit to the external audit is related to the availability of internal auditors. It can be argued that in-house internal auditors are likely to be more available than those from an outside provider as outsourced audit teams have limited contact with the company (James, 2003). Hence, availability could lead to greater external auditor reliance on an in-house internal audit function, regardless of any differences in perceptions of internal audit quality.

Research evidence relating to the impact of internal audit outsourcing on external auditors' decisions to rely on internal audit work is limited to just two studies. Glover et al. (2008) predict that external auditors rely more on work performed by outsourced internal auditors than by in-house internal auditors because the latter are closely aligned with management. Their results support this prediction

\footnotetext{
${ }^{1}$ This argument is used to support the use of co-sourcing whereby an in-house internal audit function uses the services of an outside provider for specialist tasks or at peak times. Co-sourcing is not considered in the present study.
} 
but only when inherent risk is high. Gramling and Vandervelde (2006) found a group affiliation bias when internal audit services are performed by another public accounting firm. Both internal and external auditors participated in their study, with the external auditors assessing internal audit objectivity to be higher when the provider was another accounting firm and the internal auditors assessing objectivity to be higher when internal audit was provided in-house. Given that the outsourcing arrangement in Glover et al. (2008) was also to a Big Four accounting firm, the presence of a group affiliation bias in that study cannot be ruled out.

In the present study, we minimise the likelihood of group affiliation bias by designating the outside provider as a specialist internal audit and business risk consulting firm rather than a public accounting firm. Furthermore, we contrast the outside provider with a high quality, well resourced in-house internal audit function to assess whether external auditors' reliance decisions are affected by the sourcing arrangement in these circumstances.

In light of the arguments presented above, we predict that external auditors would perceive a specialist internal audit consulting firm to be more independent than an in-house internal audit function. As such, they are likely to rely on work already undertaken by internal audit when the function is outsourced. However, following Felix et al. (2001 and 2005), we expect that the greater availability of in-house internal auditors is likely to lead to a greater use of internal auditors as assistants compared to when internal audit is outsourced. This leads to the following hypotheses:

H3: External auditors are more likely to rely on work already undertaken by internal audit when the internal audit function is outsourced to a specialist provider compared to when it is provided in-house. 
H4: External auditors are more likely to use internal audit to assist in performing audit tasks when the internal audit function is provided in-house compared to when it is outsourced to a specialist provider.

\subsection{The joint effect of sourcing arrangement and consulting role}

DeZoort et al. (2001) draw on attribution theory and other psychology research to argue that external auditor reliance on the work of internal audit should decrease in proportion to the number of incentives that internal auditors have to bias their reports. However, they find an unexpected interaction between their independent variables of internal audit participation in consulting activities and entitlement to incentive compensation. The authors tentatively suggest that this might be because external auditors are reluctant to reduce their own testing beyond a minimum threshold. In the context of our study, we therefore explore, without making a prediction, whether there is an interaction between sourcing arrangement and involvement in consulting. This gives rise to the following research question:

RQ1: Is there an interaction effect between involvement in consulting and sourcing arrangement on external auditors’ reliance decisions?

\section{Research methods}

In order to test our hypotheses, we use a 2 x 2 between-subjects design, resulting in four cases. The first independent variable is whether or not internal audit performs a systems consulting role with respect to the company's financial system. The second independent variable, the internal audit sourcing arrangement, is manipulated as being in-house or outsourced to a specialist provider. The research instrument was tested using a group of final year auditing students, academics with auditing experience and four audit practitioners. The preliminary testing confirmed the strength of the 
manipulations. However, as the study was not administered in a controlled environment, we did not include specific manipulation checks to minimise the possibility of demand effects. $^{2}$

\subsection{Participants}

Participants in the study consisted of 17 partners, 29 managers and 20 seniors from the Big Four and two mid-tier audit firms in five major Australian cities. A partner in each firm agreed to distribute copies of the instrument to colleagues who had clients with an internal audit function. Responses were mailed directly to the researchers in a reply-paid envelope. A total of 98 instruments were distributed, with 66 usable responses being received, giving a response rate of $67 \%$.

While the mid-tier firms agreed to participate, only four responses were received from these firms, owing to a lack of clients with internal audit functions. ${ }^{3}$ Approximately 58\% of participants were males. Responses with respect to age group indicated that 51.5\% were between 21 and 30, 28.8\% were between 31 and 40 and $19.7 \%$ were over 40 years of age. The mean years of experience were 10.8 , ranging from a minimum of two years to a maximum of 36 years. The number of clients using internal auditors varied from one to twelve, with a mean of four. Analyses of variance (ANOVA) and co-variance (ANCOVA) were used to test for differences in responses due to firm, rank, age, gender and experience. None of these factors had a significant impact on our reported results.

\footnotetext{
${ }^{2}$ Data for another study on external auditors' reliance decisions was collected in the same research instrument. Hence the instrument contained two scenarios, each followed by a series of questions. To reduce the risk of confounding effects, the four versions of one scenario were randomly mixed with the four versions of the other. This resulted in 16 versions of the instrument. Importantly, it should be noted that we did not change the order of the two scenarios and hence there are no order effects to consider.

${ }^{3}$ We also test our hypotheses omitting these four respondents. Results are reported in footnotes 4 and 5.
} 


\subsection{The scenario}

The scenario used in the experiment described a listed company in the paper packaging industry. Background information indicated that the company was profitable, with a sound performance trend and strong corporate governance. Over the last two years, the company had been installing enterprise resource planning (ERP) technology to integrate its business and information processes, including its financial systems. Participants were told that their firm had recently been appointed as auditor and the client's management had expressed a desire for a close working relationship between external and internal audit. This would involve the exchange of audit plans, programs, findings and reports. The firm had also been asked to consider the extent to which the audit team could rely on the work of internal audit.

\subsection{Independent variables}

The first independent variable is internal audit's involvement or otherwise in a systems consulting role. In the consulting role condition, participants were told that approximately $50 \%$ of internal audit time was devoted to assurance work and $50 \%$ to systems consulting. Internal audit had been heavily involved in installing ERP technology to integrate its business and information processes, including its financial systems. During the system-design phase, internal audit assisted in the establishment of system access for employees and in the development of the user authorisation request and approval process. In addition, the internal audit information systems specialists had just designed and implemented an analysis tool to test segregation of duty controls at various transaction levels. In the alternative treatment condition, participants were told that approximately $50 \%$ of internal audit time was devoted to assurance work and $50 \%$ to special projects such as performance audits. A similar 
description of the ERP installation was provided but, in this treatment, the company had engaged outside systems consultants from a large professional services firm.

The second independent variable is the sourcing arrangement. In the in-house provider condition, the company was described as having its own internal audit function with eight full time permanent staff and a budget of $\$ 1.25$ million. The Chief Audit Executive had more than ten years experience in internal audit and was a Certified Internal Auditor. He reported to the managing director on an administrative basis and functionally to the audit committee. The other staff were all qualified in either accounting or information systems. There were two internal audit managers with more than six years internal audit experience while the experience of the other staff ranged from one to five years. This description was designed to portray a well staffed, experienced and adequately resourced internal audit function. In the outsourced provider condition, participants were informed that the company did not have its own internal audit function but that it outsourced internal audit activities from a leading internal audit and business risk consulting firm. The partner-in-charge of internal audit services reported to the managing director on an administrative basis and functionally to the audit committee. Again, the internal audit budget was $\$ 1.25$ million. A specialist internal audit and business risk firm was chosen to reduce the possibility of “group affiliation” bias (Gramling and Vandervelde, 2006, p. 28) resulting from using a public accounting firm.

\subsection{Dependent variables}

Participants were asked to provide preliminary assessments of the extent to which they would be prepared to rely on work already undertaken by internal audit and also the extent to which they would be prepared to use internal audit to assist in performing audit tasks. In each case, these questions were divided into two parts, the 
first relating to the evaluation of internal financial controls and the second to substantive tests of account balances. For all four dependent variables, an 11-point scale was provided, with end points of zero (to a very limited extent) and ten (to a very great extent).

\section{Results}

\subsection{Descriptive statistics and t-tests}

Table 1 summarises the descriptive statistics for the four dependent variables. These statistics provide useful insights into external auditors' reliance decisions in the current governance environment. Panel A reports the means and standard deviations for external auditors' reliance on work already undertaken by internal audit while Panel B reports the same statistics for using internal auditors as assistants.

Prior to examining the impact of the independent variables on the four reliance decisions, we explore the overall differences between the four decisions. For reliance on work already undertaken by internal auditors, Panel A shows that the overall mean for control evaluation work is 6.05 while that for substantive testing is 4.11 . Panel B indicates that the overall means for the use of internal auditors as assistants are 5.85 for control evaluation and 4.42 for substantive testing. Given that each participant responded to each of the reliance decisions, we are able to conduct paired sample ttests to identify statistical differences in their responses.

First, we test for differences between control evaluation work and substantive testing of balances. The results of the paired sample t-tests are reported in Panel A of Table 2. Panel A shows that the differences in the overall means for both reliance on work already undertaken by internal auditors and the use of internal auditors as assistants are statistically significant $(\mathrm{p}<0.001)$. Hence, it is clear that participants expect to rely on internal audit more for control evaluation work than for substantive 
testing of balances. This finding could reflect the perception that internal auditors are likely to have greater expertise in internal control evaluation than in substantive testing.

Panel B of Table 2 reports the results of paired sample t-tests between relying on work already undertaken by internal auditors and using internal auditors as assistants. Panel B indicates that the differences in means for both control evaluation work and substantive testing of balances are not statistically significant. This finding is interesting given that ISA 610 only focuses on external auditors' reliance on work already undertaken and does not deal with the use of internal auditors as assistants. Our results suggest that, in spite of the lack of guidance provided by auditing standards, it appears that external auditors are comfortable with the practice of using internal auditors as assistants, particularly so for control evaluation work.

\subsection{Analysis of variance}

Table 3 reports the results of the analysis of variance used to test the hypotheses. Panel A shows that internal audit involvement with systems consulting has a significant impact on external auditors’ reliance decisions for control evaluation $(\mathrm{p}=$ 0.008) but not for substantive testing ( $\mathrm{p}=.942)$. Thus, there is support for $\mathrm{H} 1$ for control evaluation but not for substantive testing of balances. ${ }^{4}$ However, there are no significant differences between the outsourced provider and the in-house provider.

\footnotetext{
${ }^{4}$ It can be seen from Panel A of Table 1 that the means across the four treatment groups for reliance on work already undertaken by internal auditors range from 5.53 to 6.69 for control evaluation and 3.47 to 4.44 for substantive testing. In three of the four cells, the means in the consulting role condition are less than those in the no consulting role condition. This is in the direction predicted by Hypothesis 1 . The exception is the in-house provider/no consulting role treatment where the mean (3.75) is lower than the in-house provider/consulting role treatment (4.63). Further tests for the impact of confounding effects from biographic variables or extreme values failed to identify possible reasons for this anomalous result. However, it is of note that the standard deviation for this cell (2.89) is the highest of all the cells and the frequency distribution (untabulated) indicates that eight responses fall below four, with three participants scoring zero for this reliance decision. The remaining eight responses fall between five and eight. This suggests that there is a lack of consensus amongst participants with respect to relying on substantive testing work already undertaken by internal auditors.
} 
Thus H3 is not supported. The interaction effects between the two independent variables are not significant for either of the reliance decisions. ${ }^{5}$

Panel B reports the test results for $\mathrm{H} 2$ and $\mathrm{H} 4$ relating to the use of internal audit as assistants in performing audit tasks. Similar to the results in Panel A, only the consulting role manipulation is significantly different for control evaluation work ( $p=0.001$ ). Hence, H2 is supported for control evaluation but not for substantive testing. For Hypothesis 4, there is a marginally significant difference $(p=0.054)$ for the source provider manipulation with respect to substantive testing of balances. The means reported in Table 2 indicate that participants are more likely to use internal auditors as assistants for substantive testing when internal audit services are provided in-house compared to when they are outsourced. Thus, H4 is supported only for substantive testing. Again, the interaction effects are not significant. ${ }^{6}$

\subsection{Discussion of results}

Our results indicate that, for control evaluation work, external auditors rely less on work performed by internal audit and will also use internal auditors as assistants to a lesser extent when internal audit performs a systems consulting role. This suggests that external auditors are sensitive to the possibility of internal audit self-review as far as evaluating internal controls is concerned. This finding differs from that of DeZoort et al. (2001) who did not find support for their hypothesis that internal audit engagement in consulting activities would influence external auditor reliance decisions. These conflicting results could be due to the different nature of the

\footnotetext{
${ }^{5}$ We obtain similar results when omitting the four participants from mid-tier audit firms. Sourcing arrangement remains insignificant for both types of testing. Involvement in consulting is significant at $\mathrm{p}=.015$ for control evaluation and is not significant for substantive testing. Neither of the interaction effects is significant.

${ }^{6}$ Again, similar results are obtained when omitting the four participants from mid-tier audit firms. Sourcing arrangement is not significant for control evaluation and is marginally significant for substantive testing $(\mathrm{p}=.059)$. Involvement in consulting is significant for control evaluation $(\mathrm{p}=.002)$ but not for substantive testing. Neither of the interaction effects is significant.
} 
manipulation, with DeZoort et al. (2001) manipulating the overall extent of time spent on consulting activities by internal audit, compared to the present study's manipulation of a direct involvement in consulting related to the financial system. DeZoort et al. (2001) also suggest that their lack of a result may be due to the time period of their study which was undertaken at a time when external auditors themselves actively engaged in consulting to their audit clients. Given that our study was undertaken more recently when the provision of non-audit services is no longer acceptable, it is possible that external auditors' views have changed.

The results also indicate that participants are insensitive to possible differences in internal audit objectivity arising from the sourcing arrangement. This suggests that external auditors regard internal audit services provided by a high quality in-house function to have similar standards of objectivity to those that are outsourced to a specialist internal audit and business risk firm. This finding contrasts with that of Glover et al. (2008) who found that external auditors considered in-house internal auditors to be less objective than when internal audit was outsourced to a Big Four accounting firm. The difference in results can be explained by Gramling and Vandervelde’s (2006) suggestion that group affiliation theory leads external auditors to bias their evaluations of internal audit objectivity when the service is performed by a similar public accounting firm. Further exploration of these different results provides an opportunity for future research. Additionally, our significant finding with respect to using internal auditors as assistants for substantive testing work provides further support to Felix et al.’s (2001 and 2005) suggestion that this practice is driven by the availability of in-house internal auditors to provide such assistance. However, additional research is needed to identify why a similar result is not obtained for control evaluation work. 
While further research is needed to identify reasons for differences in our findings across the four reliance decisions, the results of our study demonstrate that future experimental research on external auditors' reliance on the work of internal audit should carefully consider the nature of the judgment being made. Specifically, when only one reliance decision is examined, it is important to recognise that the results may not be generalisable to other types of reliance decisions.

\section{Conclusion}

This study examined two factors that may influence external auditors' reliance on the work of internal audit in the current governance environment. The internal audit sourcing arrangement and internal audit's involvement in systems consulting were manipulated. The systems consulting manipulation was significant in the predicted direction for control evaluation, both when relying on work already undertaken by internal audit and when using internal auditors as assistants. However, the consulting manipulation was not significant for substantive testing. As far as the sourcing arrangement is concerned, participants generally did not differentiate between a high quality in-house function and a specialist outsourced provider when relying on work already undertaken by internal audit. However, participants were more likely to use internal auditors as assistants for substantive testing work. This finding is consistent with our prediction that the availability of internal auditors would impact on this reliance decision.

There are a number of limitations of our study which should be borne in mind when interpreting the findings. Our sample size is relatively small and, as with all experimental designs, the findings of our study may not be generalisable to other populations. We did not include manipulation checks in the instrument to avoid the possibility of demand effects in a non-controlled experiment. While our preliminary 
testing was designed to confirm the strength of our manipulations, we cannot be certain that all participants interpreted the manipulations as intended.

In spite of these limitations, our results have important implications for regulators and others concerned with the role of audit in corporate governance. The need for strong governance has led to increasing costs of compliance and hence determining the most efficient and effective balance between internal and external auditing remains a challenge. The present study highlights some additional factors that can affect external auditors' reliance on internal audit work in the current governance environment. When internal auditors engage in systems consulting, the possibility of a self-review threat is likely to reduce their contribution to the external audit. Hence, firms need to consider the trade-off between the added value from engaging internal audit in consulting activities and the additional external audit fees that could arise because of a lack of reliance on internal audit work. More in-depth analysis of this trade-off is an important avenue for future research.

Our study also has implications for experimental research on external auditors' reliance on internal audit work. A key contribution of the study is the use of four separate reliance decisions as dependent variables. The results provide further evidence that the impact of factors affecting external auditors' reliance on internal audit is sensitive to the type of judgment being made. The study therefore demonstrates the importance of differentiating between reliance decisions.

Finally, the study has highlighted a number of opportunities for further research. In addition to those avenues already noted, research could be undertaken to examine other aspects of the factors explored in this study. For example, the present study examined internal audit's involvement in consulting directly related to the client's financial system. While other studies have examined whether internal auditors 
advocate their firm's position when advising management, there are many other types of consulting work that could be examined in the context of external auditor reliance. Of note, internal auditors are playing an increasingly important role in risk management but we know little about how this impacts external auditors' decisions to rely on their work. In addition, our sourcing arrangement manipulation examined the difference between an in-house internal audit function and an outsourced internal audit provider. It is becoming increasingly common for firms to co-source internal audit services from an in-house function and an outside provider but the impact of this practice on external auditors' reliance decisions is relatively unexplored. 


\section{References}

Abdel-khalik, A.R., D. Snowball, and J.H. Wragge, 1983, The effects of certain internal audit variables on the planning of external audit programs, The Accounting Review 215-227.

Ahlawat, S. S., and D. J. Lowe, 2004, An examination of internal auditor objectivity: In-house versus outsourcing, Auditing: A Journal of Practice and Theory 23, 149-160.

American Institute of Certified Public Accountants (AICPA), 2008, AU section 322, The auditor's consideration of the internal audit function in an audit of financial statements, ACPA Vol. 1-PS.cls, July 16, 381-388.

Brody, R. G., and D. J. Lowe, 2000, The new role of the internal auditor: Implications for internal auditor objectivity, International Journal of Auditing 4, 169-176.

Caplan, D., and M. Kirschenheiter, 2000, The effects of internal audit structure on perceived financial statement fraud prevention, Contemporary Accounting Research 17, 387-428.

Cashell, J. D. and G. R. Aldhizer III, 2002, An examination of internal auditors' emphasis on value-added services, Internal Auditing 17, 19-31.

Church, B., and A. Schneider, 1992, Internal auditor involvement in internal control system design: Is objectivity impaired? Journal of Applied Business Research 8, $15-24$

Clark, M. W., T. E. Gibbs, and R. G. Schroeder, 1980, Evaluating internal audit departments under SAS No. 9: Criteria for judging competence, objectivity, and performance, The Woman CPA (July), 8-11, 22. 
Cohen, J., G. Krishnamoorthy, and A. Wright, 2004, The corporate governance mosaic and financial reporting quality, Journal of Accounting Literature 23, 87152.

Cooper, B.J., P. Leung, and G. Wong, 2006, The Aisa Pacific literature review on internal auditing, Managerial Auditing Journal 21, 822-834.

DeZoort, F. T., R. W. Houston, and M. F. Peters, 2001, The impact of internal auditor compensation and role on external auditors' planning judgements and decisions, Contemporary Accounting Research 18, 257-281.

Ernst \& Young, 2006, Trends in Australian and New Zealand internal auditing, Third annual benchmarking survey 2006 (Ernst \& Young, Australia).

Felix, W., A. Gramling, and M. Maletta, 2001, The contribution of internal audit as a determinant of external audit fees and factors influencing this contribution, Journal of Accounting Research 22, 31-53.

Felix, W.L., A. A. Gramling, and M. J. Maletta, 2005, The influence of nonaudit service revenues and client pressure on external auditors' decisions to rely on internal audit, Contemporary Accounting Research 22, 31-53.

Glover, S.M., D. F. Prawitt, and D. A. Wood, 2008, Internal audit sourcing arrangement and the external auditor's reliance decision, Contemporary Accounting Research 25, 193-213.

Goodwin-Stewart, J., and P. Kent, 2006, Relation betwen external audit fees, audit committee characteristics and internal audit, Accounting and Finance 46, 387404.

Gramling, A., M. Maletta, A. Schneider, and B. Church, 2004, The role of the internal audit function in corporate governance: A synthesis of the extant internal 
auditing literature and directions for future research, Journal of Accounting Literature 23, 194-244.

Gramling, A. A., and S. D. Vandervelde, 2006, Assessing internal audit quality, Internal Auditing 21, 26-33.

Institute of Internal Auditors (IIA), 1999, Definition of internal auditing, Available at: http://www.theiia.org/guidance/standards-and-practices/professional-practicesframework/definition-of-internal-auditing/.

Institute of Internal Auditors (IIA), 1994, The IIA's perspective on outsourcing internal auditing: A professional briefing for chief audit executives, Professional Issues Pamphlet 94-1 (Institute of Internal Auditors, Altamonte Springs, FL).

ISA 610, 2009, International standard on auditing 610: The auditor's consideration of the internal audit function, Available from: http://www.ifac.org.

James, K., 2003, The effects of internal audit structure on perceived financial statement fraud prevention, Accounting Horizons 17, 315-327.

Leung, P., B. J. Cooper, and P. Robertson, 2004, The role of internal audit in corporate governance and management (RMIT Publishing, Melbourne).

Margheim, L., 1986, Further evidence on external auditors' reliance on internal audit, Journal of Accounting Research 24, 194-205.

Margheim, L., and W. Label, 1990, External auditor reliance on internal auditors when audit risk is high: Some empirical findings, Advances in Accounting 8: 293-311.

Mills, T.Y., 1996, The effect of cognitive style on external auditors' reliance decisions on internal audit functions, Behavioral Research in Accounting 8, 4973. 
Nagy, A. L., and W. J. Cenker, 2002, An assessment of the newly defined internal audit function, Managerial Auditing Journal 17, 130-137.

Plumlee, R. D., 1985, The standard of objectivity for internal auditors: memory and bias effects, Journal of Accounting Research 23, 683-699.

Public Company Accounting Oversight Board (PCAOB), 2007, Auditing standard No. 5 - An audit of internal control over financial reporting that is integrated with an audit of financial statements, Available from: http://www.pcaobus.org/Rules/Rules_of_the_Board/Auditing_Standard_5.pdf.

Sarbanes-Oxley Act, 2002, Public Law 107-204, $107^{\text {th }}$ Cong., $2^{\text {nd }}$ sess. Washington, DC: GPO.

Schneider, A. 1985, The reliance of external auditors on the internal audit function, Journal of Accounting Research 23, 911-919.

Whittington, R., and L. Margheim, 1993, The effects of risk, materiality, and assertion subjectivity on external auditors' reliance on internal auditors, Auditing: A Journal of Practice and Theory 12, 50-64. 
Table 1

The impact of outsourcing and consultancy role on external auditors' reliance decisions: Descriptive statistics

\begin{tabular}{|c|c|c|c|c|c|c|}
\hline \multicolumn{7}{|c|}{ Means*, (standard deviations) and cell sizes } \\
\hline \multicolumn{7}{|c|}{ Panel A: Work Already Undertaken by Internal Audit (IA) } \\
\hline & \multicolumn{3}{|c|}{ Control evaluation work } & \multicolumn{3}{|c|}{ Substantive testing of balances } \\
\hline & $\begin{array}{l}\text { Consulting } \\
\text { Role }\end{array}$ & $\begin{array}{c}\text { No } \\
\text { Consulting } \\
\text { Role }\end{array}$ & Overall & $\begin{array}{l}\text { Consulting } \\
\text { Role }\end{array}$ & $\begin{array}{c}\text { No } \\
\text { Consulting } \\
\text { Role }\end{array}$ & Overall \\
\hline $\begin{array}{l}\text { Outsourced IA } \\
\text { Provider }\end{array}$ & $\begin{array}{c}5.53 \\
(2.07) \\
n=15\end{array}$ & $\begin{array}{c}6.50 \\
(1.37) \\
n=16\end{array}$ & $\begin{array}{c}6.03 \\
(1.78) \\
n=31\end{array}$ & $\begin{array}{c}3.47 \\
(2.17) \\
n=15\end{array}$ & $\begin{array}{c}4.44 \\
(2.16) \\
\mathrm{n}=16\end{array}$ & $\begin{array}{c}3.97 \\
(2.18) \\
n=31\end{array}$ \\
\hline $\begin{array}{l}\text { In-house IA } \\
\text { Provider }\end{array}$ & $\begin{array}{c}5.53 \\
(1.87) \\
n=19\end{array}$ & $\begin{array}{c}6.69 \\
(1.58) \\
n=16\end{array}$ & $\begin{array}{c}6.06 \\
(1.81) \\
n=35\end{array}$ & $\begin{array}{c}4.63 \\
(2.57) \\
n=19\end{array}$ & $\begin{array}{c}3.75 \\
(2.89) \\
n=16\end{array}$ & $\begin{array}{c}4.23 \\
(2.71) \\
n=35\end{array}$ \\
\hline Overall & $\begin{array}{c}5.53 \\
(1.93) \\
\mathrm{n}=34 \\
\end{array}$ & $\begin{array}{c}6.59 \\
(1.46) \\
n=32 \\
\end{array}$ & $\begin{array}{c}6.05 \\
(1.78) \\
\mathrm{n}=66 \\
\end{array}$ & $\begin{array}{c}4.12 \\
(2.43) \\
n=34 \\
\end{array}$ & $\begin{array}{c}4.09 \\
(2.53) \\
n=32 \\
\end{array}$ & $\begin{array}{c}4.11 \\
(2.46) \\
n=66 \\
\end{array}$ \\
\hline \multicolumn{7}{|c|}{ Panel B: Using Internal Auditors as Assistants } \\
\hline & \multicolumn{3}{|c|}{ Control evaluation work } & \multicolumn{3}{|c|}{ Substantive testing of balances } \\
\hline & $\begin{array}{l}\text { Consulting } \\
\text { Role }\end{array}$ & $\begin{array}{c}\text { No } \\
\text { Consulting } \\
\text { Role }\end{array}$ & Overall & $\begin{array}{l}\text { Consulting } \\
\text { Role }\end{array}$ & $\begin{array}{c}\text { No } \\
\text { Consulting } \\
\text { Role }\end{array}$ & Overall \\
\hline $\begin{array}{l}\text { Outsourced IA } \\
\text { Provider }\end{array}$ & $\begin{array}{c}5.33 \\
(2.29) \\
n=15\end{array}$ & $\begin{array}{c}6.88 \\
(1.31) \\
\mathrm{n}=16 \\
\end{array}$ & $\begin{array}{c}6.13 \\
(1.97) \\
n=31\end{array}$ & $\begin{array}{c}3.67 \\
(2.32) \\
n=15\end{array}$ & $\begin{array}{c}4.19 \\
(2.32) \\
n=16 \\
\end{array}$ & $\begin{array}{c}3.94 \\
(2.29) \\
\mathrm{n}=31 \\
\end{array}$ \\
\hline $\begin{array}{l}\text { In-house IA } \\
\text { Provider }\end{array}$ & $\begin{array}{c}4.74 \\
(2.68) \\
\mathrm{n}=19 \\
\end{array}$ & $\begin{array}{c}6.63 \\
(1.96) \\
\mathrm{n}=16 \\
\end{array}$ & $\begin{array}{c}5.60 \\
(2.53) \\
n=35\end{array}$ & $\begin{array}{c}4.47 \\
(2.84) \\
\mathrm{n}=19 \\
\end{array}$ & $\begin{array}{c}5.31 \\
(1.92) \\
\mathrm{n}=16 \\
\end{array}$ & $\begin{array}{c}4.86 \\
(2.46) \\
\mathrm{n}=35\end{array}$ \\
\hline Overall & $\begin{array}{c}5.00 \\
(2.50) \\
n=34\end{array}$ & $\begin{array}{c}6.75 \\
(1.65) \\
n=32\end{array}$ & $\begin{array}{c}5.85 \\
(2.29) \\
n=66\end{array}$ & $\begin{array}{c}4.12 \\
(2.61) \\
n=34\end{array}$ & $\begin{array}{c}4.75 \\
(2.17) \\
n=32\end{array}$ & $\begin{array}{c}4.42 \\
(2.41) \\
n=66\end{array}$ \\
\hline
\end{tabular}

*11-point scale (0 [to a very limited extent] - 10 [to a very great extent]) 
Table 2

Paired sample comparisons of overall reliance decisions

\begin{tabular}{|c|c|c|c|c|c|}
\hline \multicolumn{6}{|c|}{ Panel A: Control evaluation work paired with substantive testing of balances } \\
\hline & \multicolumn{2}{|c|}{$\begin{array}{c}\text { Means } \\
\text { (Std. dev.) }\end{array}$} & \multicolumn{3}{|c|}{ Paired Differences } \\
\hline & $\begin{array}{c}\text { Control } \\
\text { Evaluation }\end{array}$ & $\begin{array}{l}\text { Substantive } \\
\text { Testing }\end{array}$ & $\begin{array}{c}\text { Mean } \\
\text { (Std. dev) }\end{array}$ & $\mathrm{t}$ & P value \\
\hline Work Undertaken & $\begin{array}{c}6.05 \\
(1.78) \\
\end{array}$ & $\begin{array}{c}4.11 \\
(2.46) \\
\end{array}$ & $\begin{array}{c}1.94 \\
(2.86) \\
\end{array}$ & 5.509 & 0.000 \\
\hline Using IA as Assistants & $\begin{array}{c}5.85 \\
(2.29) \\
\end{array}$ & $\begin{array}{c}4.42 \\
(2.41)\end{array}$ & $\begin{array}{l}1.42 \\
(2.84)\end{array}$ & 4.075 & 0.000 \\
\hline \multicolumn{6}{|c|}{ Panel B: Work already undertaken paired with using internal auditors as assistants } \\
\hline & \multicolumn{2}{|c|}{$\begin{array}{c}\text { Means } \\
\text { (Std. dev.) }\end{array}$} & \multicolumn{3}{|c|}{ Paired Differences } \\
\hline & $\begin{array}{l}\text { Work } \\
\text { Undertaken }\end{array}$ & $\begin{array}{l}\text { Using IA as } \\
\text { Assistants }\end{array}$ & $\begin{array}{c}\text { Mean } \\
\text { (Std. dev) }\end{array}$ & $\mathrm{t}$ & $P$ value \\
\hline Control Evaluation & $\begin{array}{c}6.05 \\
(1.78)\end{array}$ & $\begin{array}{c}5.85 \\
(2.29)\end{array}$ & $\begin{array}{c}0.20 \\
(1.74)\end{array}$ & 0.920 & 0.361 \\
\hline Substantive Testing & $\begin{array}{c}4.11 \\
(2.46)\end{array}$ & $\begin{array}{c}4.42 \\
(2.41)\end{array}$ & $\begin{array}{c}-0.318 \\
(2.20)\end{array}$ & -1.175 & 0.244 \\
\hline
\end{tabular}


Table 3

The impact of outsourcing and consultancy role on external auditors' reliance decisions: Analysis of variance

\begin{tabular}{|c|c|c|c|c|c|c|}
\hline \multicolumn{7}{|c|}{ Panel A: Work Already Undertaken by Internal Audit (IA) } \\
\hline Source of variation & \multicolumn{3}{|c|}{ Control evaluation work } & \multicolumn{3}{|c|}{ Substantive testing of balances } \\
\hline & $\begin{array}{c}\text { Mean } \\
\text { Square }\end{array}$ & $\mathrm{F}$ & $\mathrm{P}_{\text {value }}^{\wedge}$ & $\begin{array}{c}\text { Mean } \\
\text { Square }\end{array}$ & $\mathrm{F}$ & $\mathrm{P}_{\text {value }}^{\wedge}$ \\
\hline IA Provider (IAP) & .133 & .044 & .835 & .933 & .153 & 697 \\
\hline Consulting Role (CR) & 18.534 & 6.115 & .008 & .033 & .005 & .942 \\
\hline IAP x CR & .155 & .051 & .822 & 14.046 & 2.297 & .135 \\
\hline \multicolumn{7}{|c|}{ Panel B: Using Internal Auditors as Assistants } \\
\hline Source of variation & \multicolumn{3}{|c|}{ Control evaluation work } & \multicolumn{3}{|c|}{ Substantive testing of balances } \\
\hline & $\begin{array}{l}\text { Mean } \\
\text { Square }\end{array}$ & $\mathrm{F}$ & $\mathrm{P}$ value $^{\wedge}$ & $\begin{array}{c}\text { Mean } \\
\text { Square }\end{array}$ & $\mathrm{F}$ & $\mathrm{P}_{\text {value }}^{\wedge}$ \\
\hline IA Provider (IAP) & 2.933 & .635 & .429 & 15.279 & 2.661 & .054 \\
\hline Consulting Role (CR) & 48.153 & 10.420 & .001 & 7.567 & 1.318 & .127 \\
\hline IAP x CR & .491 & .106 & .745 & .414 & .072 & .789 \\
\hline
\end{tabular}

$\wedge$ One-tailed when in direction predicted 